\title{
Tom Wingfield's Alienation in Tennessee Williams' The Glass Menagerie: A Marxist Approach
}

\author{
Behnam Mirzababazadeh Fomeshi \\ Department of Foreign Languages and Linguistics, Faculty of Humanities, Shiraz University, Shiraz, IRAN \\ e-mail: behnam.mirzababazadeh@gmail.com
}

\begin{abstract}
Several distinguished philosophers such as Rousseau, Hegel, Feuerbach, Kierkegaard, Marx, Nietzsche, and Heidegger paid serious attention to the notion of alienation. The present paper elaborates on the notion of alienation, based on Marx's ideas, and traces it in the character of Tom Wingfield, one of the major characters in Tennessee Williams' The Glass Menagerie. The Wingfields belong to the middle class living in the capitalist society of America during the Great Depression of the 1930's. The father has left the family sixteen years ago. The son, Tom, is the breadwinner of the family. As a "poet with a job in a warehouse," he is alienated from his labor. As a result of alienation from his labor he is self-alienated. The specialization in the capitalist system prevents him from developing to the total human and alienates him from his species life. The selfalienated worker becomes alienated from his family members and finally leaves them.
\end{abstract}

Keywords: Alienation, Tennessee Williams, The Glass Menagerie, Karl Marx.

\section{INTRODUCTION}

Several distinguished philosophers such as Rousseau (1712-1778), Hegel (1770-1831), Feuerbach (18041872), Kierkegaard (1813-1855), Marx (1818-1883), Nietzsche (1844-1900), and Heidegger (1889-1976) paid serious attention to the notion of alienation. In the observation of the philosophical concerns of these thinkers a point of convergence may be found in the assertion that our condition as human beings, for the most part, exists in alienation. They depicted it in such ways that one cannot help, but accept it as a part of reality of his/her existence.

This paper mainly refers to Marx's definition of alienation because Marx was the most closely associated with and thus made the most contributions to the concept of alienation. According to Marx, alienation, "entfremdung" in German, is not rooted in the mind or in religion, as it was for his predecessors Hegel and Feuerbach. "Instead, Marx [understands] alienation as something rooted in the material world. Alienation [means] loss of control, specifically the loss of control over labour" (Cox, 2008, p. 3).

Among the definitions of the word "alienation," two definitions, namely, "the action of estranging, or the state of estrangement," and "the action of transferring ownership to another" (Onions, 1936, p. 43) seems to be fittest here since both of them imply feelings of isolation, loneliness and lack of self-realization. Fromm (1980) in Marx's Concept of Man writes human "is not what he ought to be, and that he ought to be that which he could be" (p. 47). Alienation is estrangement from what human could be.

While Marx's theory of alienation is applicable to every kind of person, this paper focuses on the working class in the capitalist society, because "Marx assumed that the alienation ..., while existing throughout history, reaches its peak in capitalist society, and that the working class is the most alienated one" (Fromm, 1980, pp. 49-50). Marx believed that alienation is a systematic result of capitalism. To Karl Marx the problems of the system were apparent when the capitalist system was still young. He noted that:

On the one hand, there have started into life industrial and scientific forces, which no epoch of the former human history had ever suspected. On the other hand, there exist symptoms of decay, far surpassing the horrors of the Roman Empire. In our days everything seems pregnant with its contrary. Machinery, gifted with the wonderful power of shortening and fructifying human labour, we behold starving and overworking it. The new-fangled sources of wealth, by some strange weird spell, are turned into sources of want. The victories of art seem bought by loss of character (as cited in Cox, 2008, p. 2). 
The major American dramatist, Tennessee Williams (1911-1983) has reached an international reputation. He is "known for icons of world theatre such as The Glass Menagerie (1945), A Streetcar Named Desire (1947), and Cat on a Hot Tin Roof (1955)" (Millichap, 2007, p. 207). Hooti (2011) highlights "the problematic nature of the theme of alienation in the twentieth century" (p. 28), Aloostany (2011) makes mention of various versions of alienation as a prevalent theme in contemporary American fiction ( $\mathrm{p}$. 62), and Debusscher (1997) refers to Williams' confrontation "with the alienating aspects of industrial Civilization" (p. 168). The present paper elaborates on the notion of alienation, based on Marx's ideas, and traces it in the character of Tom Wingfield, one of the major characters in "Williams' most performed play" (Paller, 2005, p. 33). The Glass Menagerie at the same time that the writer acknowledges the play itself is so filled with various suggestions of atmosphere and character that any analysis in a space less than the play itself would not do justice to it.

The Wingfields are from the middle class living under the operation of the brutal economic laws of capitalist society during the Great Depression of the 1930's. "There is a powerful sense ... that the animating myths of America have failed those who look for some structure to their lives" (Bigsby, 1997, p. 35). Tom Wingfield, a "poet with a job in a warehouse" (Williams, 1966, p. VII), is the breadwinner of the family. He can be deemed the most significant character of the play "for we see not the characters but Tom's memory of them" (King, 1987, p. 76). He is an alienated worker. The alienation from labor leads to his alienation from his family, and finally he leaves home. The Glass Menagerie is "the great American play," (Hale, 1997, p. 27) and through the character of Tom, Williams gives meaning to the life of the American middle class citizens of the 1930's. Marx's concept of alienation divides into four branches: alienation of individuals from their labor, from themselves, from human's species life, and from other human beings.

\section{ALIENATION OF LABOR}

To grasp the "alienation of labor" intended by Marx one should realize what labor according to the German philosopher means. He believes,

"Labor is, in the first place, a process in which both man and nature participate, and in which man of his own accord starts, regulates, and controls the material relation between himself and nature. He opposes himself to nature as one of her own forces, setting in motions arms and legs, head and hands, the natural forces of his body, in order to appropriate nature's produc- tions in a form adapted to his own wants .... We presuppose labor in a form that stamps it as exclusively human." (as cited in Fromm, 1980, p. 40).

For Marx labor is the distinguishing mark between human and animals. It is a means of self-expression, self-development, and self-realization. It "is not only a means to an end - the product - but an end in itself, the meaningful expression of human energy; hence work is enjoyable" [italics mine] (Fromm, 1980, pp. 41-42).

In Alienated Labor Marx explains how this enjoyable labor turns into an alienated one. He writes,

"What constitutes the alienation of labor? First, that the work is external to the worker, that this is not part of his nature; and that, consequently, he does not fulfill himself in his work but denies himself, has a feeling of misery rather than wellbeing, does not develop freely his mental and physical energies but is physically exhausted and mentally debased. ... His work is not voluntary but imposed, forced labor. It is not the satisfaction of a need, but only a means for satisfying other needs. Its alien character is shown by the fact that as soon as there is no physical or other compulsion it is avoided like the plague. External labor, labor in which man alienates himself, is a labor of self-sacrifice, of mortification. Finally, the external character of the work for the worker is shown by the fact that it is not his own work but work for someone else, that in work he does not belong to himself but to another person" (Marx, 1980, pp. 98-99).

This alienation from labor is very obvious in Tom's character. Tom Wingfield is "a poet in a warehouse" (Williams, 1966, p. VII). It is not surprising if a poet be alienated in such a place. The temper of work in a warehouse does not satisfy his poetic ambitions; he does not feel at home in such a place. His "ambitions do not lie in the warehouse" (695) so he cannot fulfill himself at work. Her mother, Amanda understands the fact, but she believes that he has to "make sacrifices" (38). As indicated above, in the passage quoted from Marx, the alienated labor is a "labor of self-sacrifice." Tom, as an alienated worker, is sacrificing himself in the warehouse. Marx (1980) writes "The worker therefore feels himself at home only during his leisure time, whereas at work he feels homeless" (p. 98). To compensate for this selfsacrifice Tom goes to the movies. In Scene IV, in a dialogue with Amanda, he mentions this fact and his alienation from labor. 
Amanda Why do you go to the movies so much, Tom?

Tom I go to the movies because-I like adventure. Adventure is something I don't have much at work, so I go to the movies. (Williams, 1966, p. 39)

After this dialogue the image on the screen is sailing vessel with a Jolly Roger. This image foreshadows the decision of Tom to escape from his alienated labor and to enroll in The Union of Merchant Seamen.

According to Marx (1980), alienated worker "does not develop freely his mental and physical energies but is physically exhausted and mentally debased" (p. 98). The physical exhaustion and the mental debasement of Tom are depicted in the following dialogue.

Amanda I think you've been doing things that you're ashamed of. That's why you act like this. I don't believe that you go every night to the movies. Nobody in their right minds goes to the movies as often as you pretend to. People don't go to the movies at nearly midnight, and movies don't let out at two A. M. Come in stumbling. Muttering to yourself like a maniac! You get three hours sleep and then go to work. Oh, I can't picture the way you are doing down there. Moping, doping, because you're in no condition.

Tom (wildly) No, I'm in no condition.

(Williams, 1966, p. 27)

Through an alienated labor the product becomes so completely alienated from the producer that it is in opposition to him. This characteristic displays a strong and intense alienated relationship of the worker to the product. In Scene VI Tom expresses his attitude toward his alienated work, and mentions his decision to get rid of it in the following speech.

Tom I'm planning to change. (He leans over the rail speaking with quiet exhilaration. The incandescent marquees and signs of the first-run movie houses light his face from across the alley. He looks like a voyager.) I'm right at the point of committing myself to a future that doesn't include the warehouse and Mr. Mendoza [his employer] or even a night-school course in public speaking.

(Williams, 1966, p. 75)

Again the image on the screen is the sailing vessel with Jolly Roger.
After introducing and elaborating the notion of "alienated labor", Marx asks the following questions: "If the product of labor is alien to [the worker] and confronts [him/her] as an alien power, to whom does it belong? If [his/her] own activity does not belong to [him/her] but is an alien, forced activity, to whom does it belong?" (Marx, 1980, p. 104). These questions are answered in the following part.

\section{SELF-ALIENATION OF THE WORKER}

Marx's answer to the questions is "The alien being to whom labor and the product of labor belong, to whose service labor is devoted, and to whose enjoyment labor goes, can only be man himself" (Marx, 1980, p. 104). Then he explains what is self-alienation, how it comes to existence, and in what ways it is the result of alienated labor. In Alienated Labor Marx (1980) writes,

"The relationship of labor to the act of production within labor. This is the relationship of the worker to his own activity as something alien and not belonging to him, activity as suffering (passivity), strength as powerlessness, creation as emasculation, the personal physical and mental energy of the worker, his personal life (for what is life but activity?) as an activity which is directed against himself, independent of him and not belonging to him. This is selfalienation as against the above-mentioned alienation of the thing" (pp. 99-100).

In this first mode of alienation that is alienated labor, the worker becomes alienated from his labor and its product which exist outside him/her. So this mode of alienation is a form of alienation in the outside world. The second seminal mode of alienation that Marx discusses is that of alienation from human's own self. Therefore, it is a mode of alienation in the inner world of the worker. It is the alienated labor that leads to the alienation of the worker from his/her own self. Human's self becomes alien to him/her in this labor process because the worker is working to produce something for someone or something other than him/herself.

A dialogue between Tom and Amanda in Scene III reveals Tom's self-alienation.

$\begin{array}{ll}\text { Tom } & \text { What in Christ's name I- } \\ \text { Amanda (shrilly) Don't use that- } \\ \text { Tom } & \text { Supposed to do! } \\ \text { Amanda } & \text { Expression! Not in my- } \\ \text { Tom } & \text { Ohhh! } \\ \text { Amanda } & \begin{array}{l}\text { Presence! Have you gone out of } \\ \text { your senses? }\end{array} \\ \text { Tom } & \text { I have, that's true, driven out! }\end{array}$


Amanda What is the matter withy you, you - big — big-IDIOT!

Tom Look-I've got no thing, no single thing-

Amanda Lower your voice!

Tom In my life here that I can call my own! Everything is.

(Williams, 1966, p. 24)

Marx (1980) writes "The more the worker expands himself in [the alienated] work the more powerful becomes the world of objects which he creates in face of himself, the poorer he becomes in his inner life, and the less he belongs to himself" [italics mine] (p. 96). Tom as an alienated worker in the warehouse has got "no thing" in his life. Even his self does not belong to him. His alienated labor in the warehouse leads to his self-alienation. This is what Marx calls self-alienation of the worker which is the result of alienated labor.

Throughout the play Amanda mentions Tom's drunkenness. Tom's act of drinking can be viewed as a reaction to his self-alienation. Under the influence of alcohol he forgets the misery of self-alienation. As an alienated worker in the warehouse his labor seems "something alien and not belonging to [himself]" (Marx, 1980, p. 99). One of the functions of the drink is that it helps the drinking person think he/she is someone else in his/her fantasy. In the same way, drunken Tom can consider himself as someone else to whom his labor belongs, so he gets rid of his selfalienation for a short period of time.

\section{ALIENATION FROM MAN'S SPECIES LIFE}

To realize what Marx means by "alienation from man's species life" one should, first of all, become familiar with human as a "species-being." Marx (1980) writes "The practical construction of an objective world, the manipulation of inorganic nature, is the confirmation of man as a conscious speciesbeing, i.e. being who treats the species as his own being or himself as a species-being" (p. 102). Then he explains the role of labor in the construction of human as a "species-being" through following lines.

"It is just in his work upon the objective world that man really proves himself as a speciesbeing. This production is his active species life. By means of it nature appears as his work and his reality. The object of labor is, therefore, the objectification of man's species life; for he no longer produces himself merely intellectually, as in consciousness, but actively and in a real sense, and he sees his own reflection in a world which he has constructed" (Marx, 1980, p. 102).
What does happen when the object of labor becomes alienated (through an alienated labor)? Marx (1980) answers, "Thus alienated labor turns the species life of man ... into an alien being .... It alienates from man his own body, external nature, his mental life and his human life" (p. 103).

John (1976) believes "Marx considers as social activity not only those forms of activity that are directly communal but also individual activity" (p. 161). That is why Tom does not enjoy not only in his work and communal activities, but also in his entertainments such as going to the movies.

The failure in the development of the total human is the result of "alienation from man's species life." Fromm (1980) writes,

"Marx's central criticism of capitalism is not the injustice in the distribution of wealth; it is the perversion of labor into forced, alienated, meaningless labor, hence the transformation of man into a "crippled monstrosity." Marx's concept of labor as an expression of man's individuality is succinctly expressed in his vision of the complete abolition of lifelong submersion of a man in one occupation. Since the aim of human development is that of the development of the total, universal man, man must be emancipated from the crippling influence of specialization" [italics mine] (p. 42).

Cox, (2008) too, in his An Introduction to Marx's Theory of Alienation, refers to people's involvement in "different branches of production or crafts" prior to capitalism, and specialization "which realised only one or two aspects of their human powers at the expense of all the others" in the capitalist systems" (p. 19). In all previous societies," Marx writes, human has been "a hunter, a fisherman, a shepherd, or a critical critic," but the capitalist system "mutilate[s] the laborer into a fragment of a man" (as cited in Fromm, 1980, p. 52).

Tom refers to this mutilation and fragmentation of human in capitalist society when he says "man is by instinct a lover, a hunter, a fighter, and none of these instincts are given much play in the warehouse!" (Williams, 1966, p. 40). Warehouse symbolizes capitalist society. According to Dupre, there is an ominous "antisocial quality" attributed to the division of labor (as cited in Reynolds, 1991, p. 525). Each of "a lover," "a hunter," and "a fighter" is a constituent of human personality; they together constitute the total human. Since they are not considered in a warehouse, an alienated worker like Tom is mutilated "into a fragment of a man." Tom understands this fragmentation and is angry with the society and the capitalist system which fail to develop the total human. 


\section{ALIENATION FROM OTHER MEN}

Marx (1980) believes human's alienation from other humans is a direct consequence of the three modes of alienation previously discussed. Alienation of human from his/her labor and its product, from him/herself, and from his/her species life leads to the condition in which "man is alienated from other men" (p. 103). One treats others the way he/she treats him/herself. What can be expected from a self-alienated person? Marx answers "what is true of man's relationship to his work, to the product of his work and to himself, is also true of his relationship to other men, to their labor and to the object of their labor." Therefore, a selfalienated person is inevitably alienated from other persons (p. 103). Fromm (1980) writes "The alienation from the human essence results in "an existential egotism" [italics mine] (p. 53).

Tom is an alienated worker. Thus he is alienated from others, and a kind of egotism is developed in his character. A dialogue between Tom and Amanda in Scene III reveals Tom's alienation from his work and from others.

Amanda What right have you got to jeopardize your job? Jeopardize the security of us all? How do you think we'd manage if you were-

Tom Listen! You think I am crazy about the warehouse? (He bends fiercely toward her slight figure.) You think I'm in love with the Continental Shoemakers? You think I want to spend fifty-five years down there in that - colotex interior! Withfluorescent-tubes! Look! I'd rather somebody picked up a crowbar and battered out my brains - then go back mornings! I go! Every time you come in yelling that God damn "Rise and Shine!" "Rise and Shine!" I say to myself "How lucky dead people are!" But I get up. I go! For sixty-five dollars a month I give up all that I dream of doing and being ever! And you say self-self's all I ever think of. Why, listen, if self is what I thought of, Mother, I'd be where he isGONE! (pointing to father's picture) As far as the system of transportation reaches! (He starts past her. She grabs his arm.) Don't grab me' Mother!

(Williams, 1966, pp. 27-28).

Tom believes working in the warehouse means "give[ing] up all that [he] dream[s] of doing and being ever." $\mathrm{He}$ is so severely alienated from his work that he says "how lucky dead people are!" This alienation from labor results in his alienation from his family. It is illuminating that he says "if self is what I thought of, Mother, I'd be where he is - GONE!" (pointing to father's picture) to justify and defend himself while in Scene VI he confesses that he is going to leave his family. The fact of leaving his family proves that "selfs all [he] ever think[s] of." In a dialogue in Scene VI he reveals his egotism.

Tom I'm a member.

Jim (reading) The Union of Merchant Seamen.

Tom I paid my dues this month, instead of the light bill.

Jim You will regret it when they turn the lights off.

Tom I won't be here.

Jim How about your mother?

Tom I'm like my father. The bastard son of a bastard! See how he grins? And he's been absent going on sixteen years! [italics mine]

(Williams, 1966, p. 77).

Some familial discords spring from alienation and isolation from each other (Karim \& Butt, 2011, p. 80). Tom does not care about his mother and sister. He is going to leave them. He does not mind the light will be turned off because he did not pay for it. He is like his father. The photograph of his father functions as a "kind of mirror displaying the very self-image with which Tom is identified" (Levy, 1993, p. 531) and foreshadows "Tom following in his father's footsteps" (Zhao, 2010, p. 36). He just thinks of himself. "There is a powerful sense not merely that the animating myths of America have failed those who look for some structure to their lives, but that those myths are themselves the root of a destructive materialism or deceptive illusion" (Bigsby, 1997, p. 35). There are critics who consider Tom's behavior as a positive one. Fordyce, (1998) for instance, views Tom's escape as "a necessary first step in establishing his own sense of self" (p. 255). It is too much egotistical. A person is not allowed to commit every crime to "establish his own sense of self". His lack of concern toward his family is blameworthy.

A worker's alienation from his work alienates him/her from other people and creates an atmosphere of enmity and hostility among the workers. Marx (1964) in Third Manuscript of Economic and Philosophical Manuscripts refers to "an inhuman power [which] rules over everything" (p. 178). Tom as the narrator of the play begins Scene VI with a rather lengthy monologue, and describes the sense of alienation dominating the warehouse through the following lines. 
He [Jim] was the only one at the ware house with whom I was on friendly terms. ... . He knew of my secret practice of retiring to a cabinet of washroom to work on poems when business was slack in the warehouse. He called me Shakespeare. And while the other boys in the warehouse regarded me with suspicious hostility, Jim took a humorous attitude toward me. Gradually his attitude affected the others, their hostility wore off and they also began to smile at me as people smile at an oddly fashioned dog who trots across their path at some distance" [italics mine] (Williams, 1966, pp. 61-62).

The inhuman condition among the alienated workers in the warehouse is not bearable for Tom. He is regarded with "suspicious hostility." Even when situation gets better, he is smiled at as "an oddly fashioned $d o g$ " not as a colleague or a human being. Marx (1966) refers to "the devaluation of the human world" (p. 95). Looking at a human being like a dog is a piece of incontrovertible evidence of the bitter fact of the human devaluation. He is smiled at like a dog "who trots ... at some distance." The distance is an implicit suggestion to alienation. In an alienated community there is a distance among the individuals not a friendly atmosphere, intimacy, or mutual trust.

\section{CONCLUSION}

From Marx's talk of alienation as demonstrated in Alienated Labor it can be concluded that capitalism is the cause of alienation. Everybody suffers alienation while members of the middle class are the most alienated. There are four modes of alienation, and these are alienations of individuals from their labor, from themselves, from human's species life, and from other human beings. "Workers in Marx's time [are] held to starvation wages while they [produce] a degree of wealth never before seen in history" (Appelbaum, 1988, p. 72) and the society of these alienated workers turns into a caricature of a real community. Marx realizes the problem and proposes a solution. For the German philosopher "the increasing development of man" and "the increasing alienation" are interwoven throughout history. His remedy for the poison of alienation is "the return of man to himself, [and] his self-realization" (Fromm, 1980, p. 43). He believes the alienation caused by capitalism is obliterated by self-realization.

The problem of alienation can be traced in the character of Tom Wingfield in Tennessee Williams's The Glass Menagerie. The Wingfields are from the middle class living in a capitalist society of America during the Great Depression of the 1930's. The father has left the family sixteen years ago. The son, Tom
Wingfield is the breadwinner of the family and supports economically his mother and sister. As a "poet with a job in a warehouse" (Williams, 1966, p. VII) he is alienated from his labor. As a result of alienation from his labor he is self-alienated. The specialization in the capitalist system prevents him from developing to the total human and alienates him from his species life. The self-alienated worker becomes alienated from his family members and finally leaves them.

\section{REFERENCES}

Aloostany, G. (2011). Quest for identity in "The Hairy Ape": A study of selected drama of Eugene O'Neill. [Unpublished thesis]. Osmania University, Hyderabad.

Appelbaum, R. P. (1988). Karl Marx: Masters of social theory. California: Sage Publication.

Bigsby, C. W. E. (1997). Entering The Glass Menagerie. In M. C. Roudane (Ed.), The Cambridge companion to Tennessee Williams (pp. 29-44). Cambridge: Cambridge University Press.

Cox. J. (1998, Summer). An introduction to Marx's theory of alienation [Supplemental material]. International socialism. Retrieved from http:// pubs.socialistreviewindex.org.uk/isj79/cox.htm

Debusscher, G. (1997). Creative rewriting: European and American influences on the Dramas of Tennessee Williams. In M. C. Roudane (Ed.), The Cambridge companion to Tennessee Williams (pp. 167-188). Cambridge: Cambridge University Press.

Fordyce, W. (1998). Tennessee Williams's Tom Wingfield and Georg Kaiser's Kashier: A contextual comparison. Papers on Language and Literature, 34(3), 250-272.

Fromm, E. (1980). Alienation. In E. Fromm (Ed.), Marx's Concept of Man (pp. 43-57). New York: Frederick Ungar Publishing Co.

Hale, A. (1997). Early Williams: The making of a playwright. In M. C. Roudane (Ed.), The Cambridge companion to Tennessee Williams (pp. 11-28). Cambridge: Cambridge University Press.

Hooti, N. (2011). Quest for identity in Tennessee Williams "The Streetcar Named Desire." Studies in Literature and Language, 2(3), 18-29.

John, P. M. (1976). Marx on alienation: Elements of a critique of capitalism and communism. Calcutta: Minerva Associates.

Karim, A. \& Butt, N. R. (2011). Mothers in Eugene O'Neill's strange interlude and long day's journey into night. Linguistic and Literary Broad Research and Innovation, 2(1), 79-91.

King, T. L. (1987). Irony and distance in the glass menagerie. In H. Bloom, (Ed.), Modern critical 
views: Tennessee Williams. New York: Chelsea House Publishers.

Levy, E. P. (1993). Through soundproof glass: The prison of self-consciousness in The Glass Menagerie. Modern Drama, 36, 529-537.

Marx, K. (1964). Third Manuscript. Karl Marx: Early writings. (T. B. Bottomore, Trans., Ed.). (pp. 145-220). New York: McGraw-Hill Co.

Marx, K. (1980). Alienated labor. In E. Fromm, (Ed.), Marx's concept of man, (pp. 93-109). New York: Frederick Ungar Publishing Co.

Millichap, J. (2007). The Tennessee Williams encyclopedia. Southern Quarterly, 44(4), 206-208.
Onions, C. T. (1936). Alienation. In The shorter Oxford English dictionary (p. 43). Oxford: Clarendon Press.

Paller, M. (2005). Gentlemen callers: Tennessee Williams, homosexuality, and midtwentieth-century drama. New York: Palgrave Macmillan.

Reynolds, J. (1991). Failure of technology in The Glass Menagerie. Modern Drama, 34, 522-527.

Williams, T. (1966). The Glass Menagerie. New York: New Directions.

Zhao, J. (2010). A comparison of Tennessee Williams and Anton Chekhov. Studies in Literature and Language, 1(3), 35-38. 